\title{
DIE SKRIFBESKOUING VAN KARL BARTH.
}

Karl Barth gaan in sy Skrifbeskouing uit van die grondslag, dat ons die Woord van God in sy drie gestaltes leer ken: 1. Die geopenbaarde Woord van God, 2. Die geskrewe Woord van God, 3. Die verkondigde Woord van God. Waar ons ons hier gaan besighou met die tweede gestalte van Gods Woord, die geskrewe Woord, die Heilige Skrif, daar moet ook dadelik bygevoeg word, dat ons nie een van hierdie gestaltes los van die ander kan verstaan nie. Ons kan wel onderskei, maar nooit skei nie, sonder om in growwe dwalinge te verval nie. In hierdie drievoudige gestalte is die een, ewige Woord van God gegee, en moet ons dit probeer verstaan. Wel is dit die eerste gestalte wat die beide ander fundeer en voed, maar ook hy ontmoet ons nergens of nooit abstrak nie, juis hom ken ons net indirek uit die Skrif en in die verkondiging. Sover die verkondiging op die openbaringsgetuienis van die Skrif rus, en also gehoorsame herhaling van die Bybelse getuienis is, is dit nie minder Woord van God as die Bybel self nie. En sover die Bybel werklik van die Openbaring getuig, is hy nie minder Gods Woord as die Openbaring self nie. Die verkondiging van die Kerk rus dus op die Skrif, en die Skrif weer op die openbaring.

In die gebeurtenis van die Openbaring gaan dit om Jesus Christus, also om die eie, letterlike, en hierdie keer werklik onmiddelbare, deur God self gesproke Woord. Wat daar gebeur het is dit: God was met. ons, met ons sy vyande, met ons, die deur sy toorn getrefdes en geslaandes. Sy Woord het vlees van ons vlees en bloed van ons bloed geword. Sy heerlikheid is gesien, hier in die diepte van ons situasie. Dit het gebeur, midde in die menslike geskiedenis, en as 'n deel van hierdie geskiedenis, egter nie soos ons menslike geskiedenis gewoond is om plaas te vind nie, n.l. voortsetting en aanvulling behoewend nie, maar midde in die stroom van wording, in die see van onafgeslotenheid, van veranderbare en veranderende gebeurtenisse, die eenmalige, die beslissende, die afgeslote gebeure, die vervulde tyd. En in die Bybel gaan dit nou in alle gevalle om die menslike poging om die Woord van God in bepaalde menslike situasies, b.v. met die oog gerig op die gekompliseerde politieke posisie van Israel tussen Egipte en Babilonië. of op die dwalinge en verwarringe in die Christelike Gemeente van Korinthe, in menslike gedagtes en woorde te herhaal en weer te gee.

Dis hierdie gebeurtenis wat die Ou Testament as woord van die profesie, en die Nuwe Testament as woord van vervulling, maar beide as plaasgevind, afsluitend, volkome en genoegsaam gebeur, verkondig. Hierdie vervulde tyd, wat met Jesus Christus identies is, hierdie „dit is volbring," hierdie Deus dixit (God het gespreek), waarvan daar geen analogie is nie, is die Openbaring waarvan die Bybel getuig. En die Bybel verstaan, sou van begin tot end, van vers tot vers beteken: 
verstaan hoe alles in hom daarop as op sy onsigbaar-sigbare middepunt betrokke is. Hierdie gebeurtenis van die Openbaring, hierdie ,God met ons." het as las op die Bybelse getuies gekom, en wil deur hulle immer opnuut oor die Kerk kom en uitgeroep word as die dringendste wat elke tyd en elke mens in elke opsig kan en moet hoor.

Die Kerk vind dan ook in die Heilige Skrif 'n grootheid wat teenoor hom staan met normatiewe krag. Die Heilige Skrif is Gods Woord aan en vir die Kerk. Deur die Heilige Skrif word die Kerk tot sy verkondiging opgeroep, gemagtig en gelei. Wat in die Hervormingstyd gebeur het, sê Barth, is dit: die Kerk sien weer dat hy Christus met sy gawes, nie immanent, in homself besit, soos die Roomse Kerk leer nie, maar van sy Woord wat van buite na hom toe kom, moet vind.

Ons kom dan as vanself tot die beskouing van Barth t.o.v. die Kanon. Op die vraag, waarom juis die geskrifte wat saamgevat is in die Oue en Nuwe Testament as reël van die waarheid, as Kanon van die Kerk gestel is, antwoord Barth: eenvoudig omdat die Bybel hom tot Kanon maak. Hy is Kanon omdat hy hom as sulks op die Kerk geïmponeer het en altyd weer imponeer. Die Bybel is Kanon, omdat hy dit is. Dit kan alleen as 'n feit gekonstateer word, maar nadat dit gedoen is, is dit ook tog nie onmoontlik om nabetragtend, eksegeties aan te gee, waarin hierdie sig-imponere van die Bybel bestaan nie. Dit is geleë in die inhoud van die Bybel, wat soos reeds kortliks aangedui is, beteken: die profeties-apostoliese woord, getuienis, prediking van Jesus Christus. Die belofte van hierdie woord aan die Kerk, is die belofte van Gods barmhartigheid: God met ons, wat onsself in die diepste nood om nie met God te kan wees nie, gebring het en gedurig weer bring. Die Heilige Skrif is die woord van sulke mense, wat na hierdie Immanuel verlang het, Hom verwag het, op Hom gehoop het, en eindelik in Jesus Christus gesien, gehoor en betas het. Hulle sê, hulle getuig, hulle verkondig dit en beloof hierdeur dat dit ons ook geld. Skrif van so in inhoud is Heilige Skrif. Waar die Kerk hierdie woorde gehoor het, daar het hy 'n gebiedende, 'n laaste woord gehoor, 'n woord wat hy met geen ander meer kan verwissel en op gelyke vlak stel nie.

Wat die Heilige Skrif is, moet ons in en met die Kerk erken, want dis die Kerk wat hierdie Skrif as Heilige Skrif ontdek het. Maar Barth voeg daar dadelik aan toe dat ons met die erkenning van die Skrif in en met die Kerk, juis sê dat dit nie ons menslike saak kan wees om die een of ander geskrif as Heilige Skrif, as getuienis van God openbaring te bepaal en uit te kies nie. Waar daar so 'n getuienis en die aanneming van so $\mathrm{n}$ getuienis is, kan dit net daarom gaan dat dit assulks reeds bepaal en uitgekies is, en by die aanname daarvan kan dit net gaan om die ontdekking en erkenning van hierdie reeds plaasgevonde 
bepaling en uitkiesing. Die Kerk kan die Kanon nie skep nie, net vasstel as reeds geskep en gegee. Ons hoor also wel die oordeel van die Kerk, ons gehoorsaam egter nie sy oordeel as ons ons aansluit by daardie oordeel wat deur die Kerk voltrek is nie, maar ons gehoorsaam in en met die Kerk die oordeel wat reeds gevel is voordat die Kerk sy oordeel vel, wat die Kerk met sy oordeel net kan bevestig. Ons sê terwyl ons die kerklike Kanon aanneem, dat nie die Kerk, maar die Openbaring self, wat die Kerk grondves en regeer, juis hierdie getuienis. in die Bybel as openbaringsgetuienis, as Kanon vir die Kerk betuig. Gods Woord is God self in die Heilige Skrif; God verstaan Hom alleen self in die Skrif; ons kan van Gods Woord geen enkele woordjie spreek nie, as $\mathrm{Hy}$ dit nie self tot ons spreek nie.

Op ons vraag na die Skrif het God 'n duidelike en definitiewe antwoord. Maar, sê Barth, ons hoor van daardie antwoord is menslik en onderworpe aan die moontlikheid om te fouteer. Daarom was dałr ook altyd 'n engere en wyere opvatting van die Kanon. Die vasstelling van die Kanon staan vir Barth dan ook gelyk aan die vasstelling van 'n dogma, in die betreklikheid van 'n menslike erkenning van die waarheid deur God aan die mens geopenbaar. Hy wys op die lang geskiedenis wat agter die vaslegging van die Kanon lê, en geraak. dan tot die slotsom dat ons moet toegee dat die konkrete gestalte van die Kanon geen absolute, maar net 'n hoogs relatiewe afgeslotenheid kan wees.

Dit beteken nou nie dat Barth goedkeuring daaraan verleen om uit geskrifte buite die erkende Kanon te preek nie. Nee, hy beklemtoon dit nadruklik dat die Kerk in die Bybel alleen sy lewe het, dat die Skrif vir die Kerk normerende openbaringsgetuienis is, dat die trou van die Kerk aan God geleë is in sy trou aan hierdie Boek. Wat die Kerk as Kanon erken, is genoeg vir tyd en ewigheid. Geen enkeling kan enige ander geskrif as Heilige Skrif bepaal nie, of die bepaalde Heilige Skrif ontken nie. As dit sover mag kom, moet dit die akte van die Kerk as geheel wees. Wat die Kerk as Heilige Skrif verklaar het, moet ons nader in die verwagting dat dit ook vir ons Woord van God kan word, wat ons ondervinding daarmee andersins ook mag gewees het.

Die Bybel is die menslike getuienis van die Openbaring. Op sigself is die Bybel dan nie Woord van God nie, maar moet dit altyd weer word. Deurdat die Bybel vir ons Openbaring word, is dit die Woord van God. Maar ons het hierdie Woord van God nie anders as die menslike woord van die Bybelgetuies nie. Wanneer ons met die Bybel te doen het, het ons met hierdie medium, met hierdie menslike woorde te doen, wat assulks nie die Openbaring is nie, maar van die Openbaring getuig. Dit is dus deur-en-deur menslike spreke waardeur God self spreek. Die mens kan met sy spreke die Woord 
van God net dien. Omdat Hy Hom deur die menslike woord laat dien, is Hyself hierdie menslike woord, en omdat die menslike woord Hom dien, is hyself die Woord van God. Ons het dus hier menslike woord. met Gods opdrag agter hom aan ons; mensewoord waaraan God Hom as voorwerp gegee het; mensewoord wat deur God as goed erken en aangeneem word; mensewoord waardeur Gods eie spreke aan ons gebeurtenis word.

Getuig beteken in 'n bepaalde rigting oor sigself uit, op 'n ander heenwys. Getuienis is also die diens aan hierdie Andere. In hierdie diens staande, wys die Bybelse getuies oor hulleself heen. As ons hulle reg wil verstaan, moet ons hulle in hulle gestalte as getuies, as heenwysende van hulleself op die Andere, verstaan. Nie terwille van hulleself, ook nie om hulle diepste innerlike besit of nood nie, maar opgeroep deur daardie Andere, praat en skryf hulle. Nie om hulleself deur te sit nie, nie as helde en advokate van die saak wat hulle verteenwoordig nie, maar anderkant alle immanente teologie, daarom, omdat van daardie Andere gepraat en geskryf moet word. Nie hulleself, ook nie en juis nie hulle besondere Godsondervinding en Godsverhouding wil hulle die Kerk aanbied en gee nie, maar deur hulleself daardie Andere.

Hierin is dan ook die eenheid van die Bybel geleë: dat ons daarin die getuienis van die Openbaring as inhoud het. Die enigste werklike verskil tussen die Oue en Nuwe Testament, is dat die Ou Testament van die komende en die Nuwe Testament van die gekome Christus getuig. Daar is in die Bybel ook die onderskeid tussen die persoonlikhede van die bekende en onbekende skrywers. Jesaja is nie Prediker nie, en Paulus nie Jakobus nie. Maar die verskil en onderskeid van die verskillende persoonlikhede word ook weer beperk en betreklik gemaak deur die eenheid van dit wat deur hulle almal gesê word.

Die Bybel getuig van homself in die bestaan van hierdie besondere mense. Hulle was in onderskeid met onsself en alle ander mense diegene wat die eenmalige Openbaring assulks en ewenwel in eenmalige wyse gesien en gehoor het. Hulle was in onderskeid met ons en alle ander mense diegene wat die Openbaring, soos dit hulle ontmoet het, aan die origes en daarmee aan ons en alle ander mense moes verkondig. In die bestaan van hierdie besondere mense word Christus vir ons werklikheid. In die uitoefening van hulle amp as eerste getuies, is hierdie mense heilige mense en samestellers van die Heilige Skrif. Barth huldig geen inspirasie van Bybelskrywers nie. Of beter gesê. Barth verwerp alle bestaande inspirasielere, die duialistiese, sowel as die organiese en meganiese inspirasielere. Juis uit vrees vir die NeoProtestantse dwaling wat bou op die mens en sy gawes, en lei tot vergoding van die wedergebore mens, wys Barth alle geïspireerdheid van die Bybelse skrywers af. Die Bybelse getuies is wat hulle is, nie 
kragtens hulle begaafdheid as denkers, as religieuse persoonlikhede en genieë, as moralistiese helde nie, hoewel hulle dit alles, reg verstaan en in verskillende mate, ook was. Wat hulle as getuies van die Openbaring, en also as siende, horende, gestuurde en gevolmagtigdes was, dit sou deur dit wat hulle intellektueel, religieus, moralisties was of nie was nie, nòg groter of kleiner, nòg beter of slegter geword het nie. Nie kragtens hulleself, nie kragtens hulle geïnspireerdheid word hulle geglo nie, maar kragtens dit wat hulle sê; daar moet altyd gesien word op Hom wat hulle stuur.

Barth is ook teen alle geïnspireerdheid van die Bybel wat hom assulks as heilige objek, as afgod tussen God en mens sou stel. Gods Woord beteken: God spreek, en dit beteken dan voor alles die geestelikheid van Gods Woord. Dit neem egter nie weg dat die Woord van God ook natuurlik-liggaamlik is nie, omdat dit daarsonder nie aan ons as geestelik-natuurlike wesens gerigte woord sou kon wees nie. Daarom, sê Barth, moet die sakrament naas die prediking kom, daarom is die prediking self ook 'n fisiese gebeurtenis, daarom heet ook die Kerk die liggaam van Christus. Die vorm van die getuienis van Gods openbaring is die getuienis van Profete en Apostels.

Die Woord van God ontmoet ons in hierdie vorm en afgesien daarvan is daar vir ons geen Woord van God nie. Ons kan by die vraag na die Openbaring ons nie van die teks losmaak nie. Maar, en daarop juis laat Barth alle klem val, die menslike bly hier menslik, sonder om goddelik te word. Daar bestaan geen persoonseenheid tussen God en die menslikheid van die Profete en Apostels nie. As Woord van God in die teken van hierdie profeties-apostoliese mensewoord, is die Heilige Skrif nie net goddelik, en ewemin net menslik, en ewemin 'n menging tussen God en mens. Maar hy is op sy wyse en sy trap soos Jesus Christus self: ware God en ware mens, d.i. getuienis van die Openbaring wat self tot die Openbaring behoort, en 'n historiese literêre dokument van 'n bepaalde mensheid.

Die Bybel is ook 'n historiese datum. Daar bestaan tussen die Bybel en ander groothede en faktore van ons menslike kosmos geen verskil, sover die Bybel ook toevallig ' $n$ historiese dokument van die geskiedenis van Oud-Israel en sy godsdiens, sover hy ook 'n dokument van 'n bepaalde lyn van die Godsdiensgeskiedenis van die Hellenisme is, en also as historiese bronneversameling te gebruik is, nie. Die mense wat ons hier as getuies van die Openbaring hoor spreek, spreek as feilbare en fouterende mense soos ons is. ' $n$ Mens kan hulle woord ook as bloot menslike woord lees en probeer waardeer. 'n Mens kan dit aan allerlei immanente kritiek onderwerp, en weliswaar nie net met betrekking tot sy wêreldaanskoulike, historiese en moralistiese, maar ook met betrekking tot sy religieuse en teologiese gehalte. 'n Mens kan leemtes, raaisels en eensydighede van sy getuienis vasstel. 'n Mens 
kan met Paulus en Jakobus diskuteer. 'n Mens moet erken dat jy met sekere dele van die Bybel niks kan uitvoer nie. 'n Mens kan jou aan sekere dele van die Bybel erg. Dis dan ook noodsaaklik dat 'n mens die Bybel histories moet lees, verstaan en uitlê. Hy is en bly menslike woord, en moet assulks ernstig geneem, gelees en verstaan word. Historiese verstaan van die Bybel moet dit beteken: dat 'n mens dit ondubbelsinnig neem wat dit is: 'n deur bepaalde mense, tot bepaalde tye, in ' $n$ bepaalde posisie, in bepaalde taal en dade, plaasgevonde menslike rede.

Maar ook as menslike woord sê die Bybel iets bepaalds, as menslike woord wys hy oor homself heen, as woord wys hy op 'n saak, 'n voorwerp. Elke menslike woord doen dit, sê Barth. Ons verstaan nie in woord as ons weet uit watter situasie en met watter doel hy gespreek is nie. Uitlê kan ook nie bestaan in die voorstelling wat ek my van die spreker makk nie. Ons hoor alleen 'n woord wanneer dit wat deur die gespreekte woord aangedui word, vir my aanskoulik word. Van dit wat die woord my so aansigtelik gemaak het, keer ek nou terug na die woord, na die spreker, en dit beteken dan verstaan. Uitlê beteken dat ek die spreker sien in die lig van die gespreekte, en vandaar sy woord ondersoek. Dit kom dan hierop neer, dat die woord van die getuie ons heenwys na dit waarvan hy getuig, na die Openbaring, na Jesus Christus, en van daaruit kan ons eers die woord van die Bybelgetuie verstaan. Barth waarsku dat ons moet waak vir die historiese betragting wat bly by die verstaan van die Bybelwoorde in hulle immanente, taalkundige en saaklike samehange, i.p.v. uit dit wat deur die Bybelwoord gesê word. Ondersoek van die menslike woord met betrekking tot die skrywer in sy historiese en persoonlike gesteldheid, is onskadelik en onnuttig, en beteken geen erns met die Bybel maak nie.

Die Bybel uit ons menslike situasie uit gesien, is dus in menslike boek soos alle ander boeke. Dit word vir ons Woord van God deurdat God deur middel van die menslike woord ons aanspreek. Nader Barth miskien hier tog die dualistiese betragtingswyse, n.l. dat ons in die Bybel mensewoord en Gods Woord het? Hy verskil van die Dualiste hierin. dat dit buite die nag en moontlikheid van die mens lê om sekere dele as mensewoord en ander dele as God Woord aan te dui. Die hele Bybel is mensewoord, maar in die mensewoord ook Gods Woord deur die goddelike genadedaad wat dit vir die mens Woord van God laat word.

Barth lê veral baie klem daarop dat dit God self is wat die handelende subjek in sy Woord is. $\mathrm{Hy}$ is die eerste outeur, die auctor primarius. Gods Woord is Gods sprekende persoon. Hy is vrye subjek. $\mathrm{Hy}$ is nie aan die Woord gebonde nie, maar die Woord aan Hom. God is die Heer van die woordelikheid van sy Woord. Hy kan dit gebruik of nie gebruik nie, Hy kan dit so of ook anders gebruik. Hy kan oor 
die woordelikheid van die Skrif uit, nuwe woordelikheid kies. Wat die Heilige Skrif verkondig as sy Woord, kan weer as sy Woord in nuwe woordelikheid verkondig word. altyd so, dat dit Hyself is wat deur hierdie woorde spreek. Hierdie persoonlikheid van die Woord van God is juis die hindernis wat opgewerp word om te verhinder dat van die Woord van die Skrif 'n menslike sisteem gemaak word. Dit noem Barth die vryheid van die Woord van God, en Gods trou aan die Kerk bestaan hierin dat hy van sy vryheid gebruik maak om in sy Woord self tot ons te kom, en dat Hy Hom hierdie vryheid voorbehou om dit immer weer te doen.

Ons ken Gods Woord dan ook nie anders as in deur God aan ons gerigte woord nie. Geabstraheerd van Gods sprekende persoon, is daar geen Woord van God nie. Gods Woord bestaan vir ons alleen daarin dat $\mathrm{Hy}$ ons aanspreek. Daar is egter geen wesensnoodwendigheid waarom God ons sou aanspreek nie. Dit kon ook anders gewees het. Die ewige verwekking van die Seun beteken dat God sonder ons nie eensaam is nie. Sy liefde het sy voorwerp in Homself. God het nie nodig gehad om tot ons te spreek nie. Wat $\mathrm{Hy}$ by Homself en met Homself spreek van ewigheid tot ewigheid, sou sonder ons daarbywees netso goed en beter gespreek wees. Net wanneer 'n mens daaroor duidelik is, kan jy waardeer wat dit beteken. dat God 'n wêreld en onsself, nie noodwendig vir Hom, maar daadwerklik geskape het; dat sy liefde, nie noodwendig vir Hom, maar daadwerklik ons geld; dat sy Woord, nie noodwendig vir Hom, maar daadwerklik tot ons gespreek is.

Dat God sy Woord tot ons spreek, is dus enkel vrye genade. Die werklike inhoud van die spreke van God is dan ook in geen opsig deur ons as algemene waarheid op te vat en weer te gee nie. God het vir elke mens altyd iets heeltemal besonders, juis hom en hom alleen aangaande te sê. Ons kan en moet weliswaar as lesers van die Skrif en as hoorders van die verkondiging met bepaalde menslik-begrypbare algemene vullinge werk. skynbaar napratend wat God tot hierdie en daardie mens gespreek het, ons sal dit egter nie moet verwissel met die konkrete volheid van Gods spreke self nie. Gans anders was altyd dit wat God gesê het, en gans anders dit wat Hy sal sê. Die Skrifwcord waardeur God tot ons spreek word tog werklik gans anders by die oorgang uit die mond van God self. Dit kom tot ons as Herewoord, as Woord van ons Skepper, die Woord van Hom wat ons bestaan en die einde van ons bestaan omgrens, die Woord wat kom as vernuwing van die betrekking tussen Skepper en skepsel, dus as versoeningswoord, as verlossingswoord. Dis 'n Woord wat ons in ons eksistensie tref, ' $n$ woord wat ons onder die heerskappy en beslissing van God stel, 'n woord wat die inhegtenisname van die mens beteken. Die Woord van God sê die mens in alle gevalle dat hy die eiendom 
van God is. Verstaan ons die Woord van God van sy oorsprong in die Openbaring, in Jesus Christus af, as die inbegrip van die genade van God, dan beteken genade dit, dat die mens nie meer aan homself oorgelaat is nie, maar in die hand van God oorgegee is.

Gods Woord is vir Barth Gods Woord, nie gebind. nie vas te stel op hierdie en daardie tese of antitese nie. Die Bybel kan dan ook net in die geloof vir ons Gods Woord word. Die erkenning dat die Bybel Gods Woord is, is 'n geloolsbelydenis. Dit beteken nou nie dat die mens ten laaste tog kan vasstel wat die Woord van God is nie. Die geloof is nie elkeen se besit nie. Ook wanneer ons dit het is dit klein en swak en onvoldoende, sodat die wonder wat moet geskied sodat die Bybel oopgaan en die Woord van God ons aangryp, altyd ook in 'n verwekking en versterking van ons geloof moet bestaan. Die geloof kom deurdat die Woord tot die mens kom en die geloof skep. Die geloof kan dan ook nie, al is dit met 'n hooggestygde energie, na die Bybel gryp nie. Veeleer kom dit eers deur die kom van die Woord van God tot die energie van hierdie gryp. Glo is dan geen eiemagtige, geen sy voorwerp magtige, maar 'n deur sy voorwerp bemagtigde erkenning, wete, hoor, spreek, dink en doen. Glo dat die Bybel Woord van God is, beteken dat die Bybel sig as Woord van God reeds betoon het, sodat ons hom daarop kan en moet erken. Die blote voorhande wees van die Bybel, en ons bestaan teenoor hom met die moontlikheid om in voorwerp te erken, beteken assulks nog nie, en beteken assulks ook nooit die werklikheid of ook die moontlikheid van die bewys dat die Bybel die Woord van God is nie. Dit kan alleen as 'n wonder gebeur. Dat die Bybel van Gods Openbaring getuig. beteken nie dat Gods Openbaring nou in een of ander openbaarheid voor ons lê nie. Die Bybel is geen orakelboek nie. Hy is geen orgaan van direkte mededeling nie. Hy is werklik getuienis. Dat die in menslike bestaanswyse tot ons kom, beteken die ergerlikheid wat die Woord van God aankleef, in muur wat tussen die Bybel en ons opgerig is. Soos ons uit onsself nie kan sê dat Jesus die Christus is nie; soook nie dat die Bybel Gods Woord is nie. Die Woord van God kom tot ons altyd in in gestalte wat assulks die Woord van God nie is nie. Deur hierdie verhulling onthul Gods Woord hom in 'n goddelike wonderdaad. Die Woord van God bly sy geheimenis.

Waar ons spreek van die gebeurtenis waarin die Woord van God aan die mens nie alleen openbaar word, maar ook deur hom geglo word. daar spreek ons van die Heilige Gees. Dat en hoe die Woord van God tot hierdie en daardie mens so gesê is dat hy dit moet hoor, dat en hoe hierdie en daardie mens so vir die Woord van God oop en bereid is dat hy dit kan hoor, dit is die werk van die Heilige Gees. Dit behoort tot die wese van die Woord van God dat dit verneembaar is. Die mens kan die Woord van God hoor. Is daar in die mens 'n 
aanknopingspunt vir die Woord van God? Barth verwerp so in moontlikheid. Hy sê: in die geloof is die mens deur die Woord van God vir die Woord van God geskape. In die geloof is die mens godegelyk, d.i. bekwaam, in staat om die Woord van God te verneem. Die herstelde beeld van God deur Christus, beteken dat die mens die Woord van God kan hoor. God is die Heer in hierdie gebeurtenis. Die Heer wat die Woord gee is ook die Heer wat die geloof gee. Die Woord van God is ook in die gebeurtenis van die geloof aan hom, Gods wonderdaad. Die Woord van God kan alleen in die Heilige Gees gehoor en geglo word.

Waar Barth sê dat die Skrif op sigself nie die Woord van God is nie maar dit deur Gods spreke daardeur word, deur die aktualisering van die Heilige Gees, daar lyk dit of hy die objektiwiteit van die Skrif nie tot sy reg laat kom nie en teoloë het dit dan ook as 'n beswaar teen sy Skrifbeskouing ingebring. Dit kom waarskynlik deurdat Barth dit so oor-en-oor beklemtoon dat daar geabstraheerd van Gods sprekende persoon geen Woord van God is nie. Dit beteken egter nie dat die Bybel vir die Kerk nou 'n gewone boek soos ander boeke is nie. Die Bybel bly vir die Kerk daardie Boek wat die getuienis bevat van die besondere mense, wat deur die Heilige Gees die Openbaring van God op eenmalige wyse gesien en gehoor het. Omdat dit werklik getuienis van die Openbaring is, daarom is dit normatief vir die lewe van die Kerk. Die Kerk kan alleen lewe deur ywerig en volhardend in getroue eksegese te wag op die sprekende stem van God deur middel van die Bybelwoord. Die mens het dit egter nie in sy mag om te bepaal en vas te stel wat en waar Gods Woord is nie. Die Kerk kan wel na die Bybel gryp, kan dit wel in ere hou, kan sig oophou en bereid maak om dit as Woord van God te lees, te hoor en te verstaan. Dit alles kan die Kerk en moet die Kerk ook doen. En as die Kerk dit doen, dan doen hy dit wel seker daarom, omdat die Kerk glo en bely dat die Bybel die Woord van God is. Maar Barth noem dit die menslike kant van die lewe van die Kerk met die Bybel. Maar daaroorheen bestaan die lewe van die Kerk met die Skrif alleen daarin dat hy om die syn van die Bybel as Woord van God elke dag, also om daardie gebeure van die werk van die Heilige Gees, om die vrye toekering van die vrye genade van God, moet bid. Die deur van die Bybelse teks kan net van binne geopen word. Dis egter iets anders of ons voor hierdie deur volhard, of na ander deure wegloop. Dis iets anders of ons ingang verlangend aan hierdie deur bly klop, of traag daar teenoor bly sit. Ons word tot trouheid en volharding opgeroep. en daardeur word ons lewe in die regte geloofspanning gehou.

Barth verwerp alle bestaande inspirasielere. Teen Barth is ingebring dat hy geen eie inspirasieleer aanbied nie. In sy vroeëre geskrifte 
mag dit wel ontbreek het, in die tweede helfte van die eerste deel van sy dogmatiek gee hy egter 'n uiteensetting van sy opvatting van die inspirasie van die Bybel. Dit kom in kort hierop neer. Hy sê dat om te glo aan die inspirasie van die Bybel dieselfde is as te glo dat die Bybel Gods Woord is. Die erkenning van die inspirasie van die Bybel beteken die erkenning en aanbidding van die soewereiniteit van Hom wie se Woord die Bybel is. Die inspirasie van die Bybel is nie iets staties nie, maar bestaan in die gedurige handeling van die genadige God wat die Bybel vir ons sy Woord laat word. Die wonder van Gods genade het eenmaal aan mense geskied om getuies te wees van sy Openbaring, en hierdie wonder moet deur hulle woord altyd weer aan ons geskied om deur Gods genade in hulle woorde die sprekende stem van God te verneem. Word dit in die tyd waar, soos dit in die ewigheid waar is, dat die Bybel Gods Woord is, dan beteken dit dat God nou deur hierdie Bybelse teks tot ons spreek. In hierdie vallende beslissing van God is die Woord van God letterlik een met die mensewoord van die Bvbelse getuie. Hierdie mense het as feilende en fouterende mense gespreek, hulle het as mense in elke woord wat hulle gespreek het, gefaal, maar geheilig en geregverdig deur Gods genade alleen, het hulle met hierdie feilbare en feilende mensewoord Gods Woord gespreek. Barth nader hier beslis die ou verbaalinspirasieleer. en hy erken ook die noodwendige en goeie reg daarvan. Maar hy iê daar 'n nuwe inhoud in. Verbaalinspirasie beteken nie: onfeilbaarheid van die Bybelse woord in sy taalkundige, historiese en teologiese karakter as mensewoord nie, maar dit beteken: die feilende en feilbare mensewoord is nou assulks deur God in sy diens geneem, en ondanks sy menslike feilbaarheid moet dit assulks aangeneem en gehoor word.

Met die oog hierop kan die historiese en die Bybelse kritiek sy weg dan gerus maar gaan.

Dat die Bybel Gods Woord is beteken nie dat dit vir my waar is deur die blote voorhande wees van die Boek assulks nie. Van die Boek assulks kan ons net dit sê: ons herinner ons dat ons hier of daar in hierdie Boek Gods Woord gehoor het; ons herinner ons in en met die Kerk dat die Woord van God ook in hierdie ganse Boek, in al sy bestanddele gehoor is; en daarom verwag ons om die Woord van God weer in hierdie Boek te hoor, in die hele Boek te hoor, ook daar waar ons dit nog nooit gehoor het nie. God is vrymagtig om ons deur enige deel van die Bybel aan te spreek. Die Woord van God is in die hele Bybel. Sonder die getuienis van die Heilige Gees in ons, kan dit egter vir ons nie Woord van God word nie.

Samevattend kan ons sê dat Barth die inspirasie so sien: die Bybelse getuies het deur Gods genade die Openbaring in eenmalige wyse gesien en gehoor. In die Bybel het ons hulle menslike getuienis 
van daardie Openbaring. In sover dit die getuienis van die Openbaring is, is dit Gods Woord. Die klem val op die woord wat hulle gespreek het, en die autoriteit van daardie woord is geleë in die saak waarna daardie woord heenwys. Daardie woord neem God nou in sy hand om ons daardeur aan te spreek. Barth stel hom dus op die standpunt van die "grafiese" inspirasie, verwerp alle geïnspireerdheid van die Bybelse skrywers, in teenstelling tot die Neo-Calvinistiese standpunt wat eers praat van die inspirasie van die Bybelskrywers, en daarna, as tweede aksie van die werk van die Heilige Gees, van die Skrifinspirasie.

Barth se opvatting van die onafgeslotenheid van die Kanon, stel ons nie tevrede nie. O.i. moet die Kanon vanuit Pinkster gesien en verstaan word. Met die uitstorting van die Heilige Gees gaan gepaard die aanname van die Outestamentiese Skrif as gesaghebbende getuienis van Jesus Christus (vgl. die rede van Petrus, Hand. 2). Die Heilige Gees sluit Hom dadelik aan by die skriftelikheid van die Woord, sodat ons nie net van die inkarnasie, vleeswording, van die ewige Logos moet spreek nie, maar ook van 'n inskripturasie, skrifwording van die Logos, die Logos van die Heilige Gees. Die Heilige Gees is die Gees van Profete en Apostels, die Gees waardeur hulle gespreek het. Soos die eenmaligheid van die vleeswording die noodwendige afsluiting van die Outestamentiese Kanon beteken. so lê in die eenmaligheid van die gebeurtenis van die Geesuitstorting die fondament en grond vir die afgeslotenheid van die hele Bybelse Kanon.

lemand het die Barthiaanse teologie gekarakteriseer as die uitwerking van die enkele sinnetjie: uit die geloof lewe beteken genade. Dit is ook van toepassing op Barth se Skrifbeskouing. Die geheel draai om drie woorde: God, genade, geloof. Dis alleen genade dat ons deur die geloof God in die Skrif kan ken. God is vir Barth die onbekende God. ook in die Skrif. Dis 'n negatiewe utispraak, maar gelaai met positiwiteit: ons ken God nie, maar God ken ons. Die Bybel is nie mensegedagtes oor God nie, maar Gods gedagtes oor die mens. Die inhoud van die Bybel, sê Barth, is God. Oor die inhoud van hierdie inhoud kan ons alleen maar stamel. Hy is meer, groter en hoër as die hoogste en skoonste waarvan ons kan dink of droom. Van hierdie God spreek die Bybel, en in hierdie Bybel is die lewenskrag van die Kerk. Ons trou aan God is geleë in ons trou aan hierdie Boek.

In sy boek ..Die Mystik und das Wort" sê Brunner dat dit in die godsdienstige wêreld vandag gaan om die beslissing tussen die mistiek aan die een kant en die Christelike geloof in die Skrif aan die ander kant. Brunner bedoel daardie mistiek wat streef na Godsgemeenskap buite die Woord om. Die Christelike geloof leef uit die Woord van God. Ook volgens die beskouing van Barth is daar vir die Kerk net 
een keuse, en mag dit vir ons Kerk, wat hom stel op die Skrif, aityd so bly: die Woord van God en die diens van sy Woord.

\section{LITERATEUER.}

F. J. VAN ZYL.

Kart. Barth, Kirchliche Dogmatiek I, 1, Zollikon, 3de druk 1939.

, . Kirchliche Dogmatiek I, 2, Zollikon 1940.

.. $\quad$.. Das Wort Gottes und die Theologie, München, 1925.

" . Offenbarung, Kirche, Theologie, Theologische Existenz Heute, 9 München. 1930.

.. .. Der Dienst am Wort Gottes. Theologische Existenz Heute, 13, München, 1934.

A. B. du Preez, Die Skrifbeskouing van Karl Barth. Onder Eigen Vaandel, VII. 3 , Wageningen, 1932 .

Dr. Th. L. HatTjema, Het Woord Gods en de Bybel. Onder Eigen Vaandel, VIII, 3, Wageningen, 1933. 